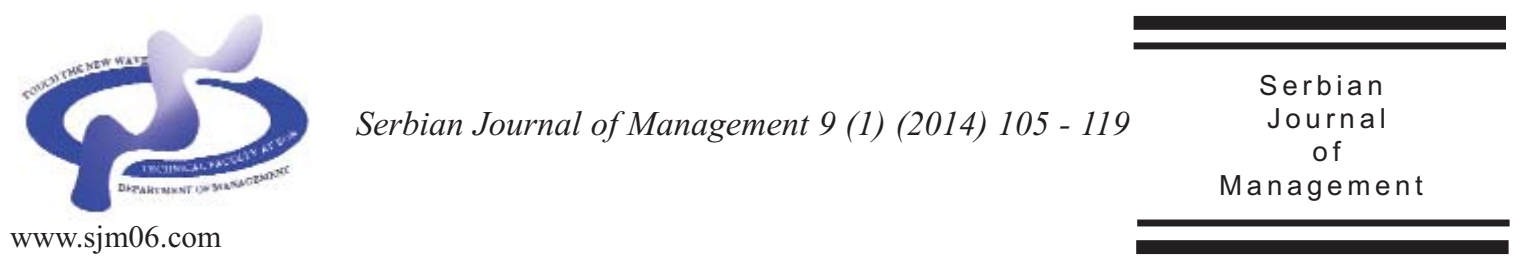

\title{
OFFSHORING FOR SUSTAINABLE VALUE MANAGEMENT
}

\author{
Thaddeus Oforegbunam Ebiringa ${ }^{a *}$ and Lasis Kule ${ }^{b}$ \\ a Department of Management Technology, Federal University of Technology, Owerri, Nigeria

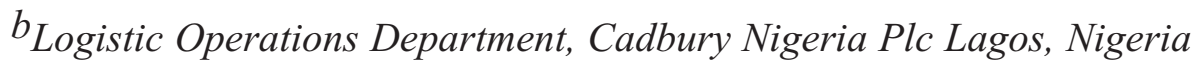 \\ (Received 6 March 2014; accepted 20 April 2014)
}

\begin{abstract}
This paper evaluates offshoring as a strategic value management initiative using Cadbury Nigeria $\mathrm{Plc}$ as a case study. Through offshoring risks associated with inventory holding are hedged. A comparative analysis of in-house and offshored cost profiles as well as critical risk factors that affect firm value are evaluated. The result shows that offshoring led to immediate costs saving, freeing of funds previously held in inventory for other working capital investments as well as profitability for vendors. However, aside financial benefits to partners, it leads to increased stakeholders awareness, shared values, partnerships, teamwork and risk mitigation. It therefore follows that for sustainability of financial benefits of offshoring, concerted effort must be made by partners to ensure that critical drivers of value management are not compromised.
\end{abstract}

Keywords: Logistics, Offshoring, Cost saving, Productivity factor, Sustainability, value creation.

\section{INTRODUCTION}

The increased use of offshoring as a value management strategy by firms globally has provoked significant debate as to whether it actually leads to sustainable financial benefits (cost savings and profitability) without value compromise (Andersson \& Pedersen, 2010). In reality, the success of offshoring can only be determined by close review of pre and post business case with focus on cost savings and value creation as critical success factors. Offshoring decisions according to Bertrand (2011) aims to:

- Achieve cost savings.

- Redistribution of business and commercial risk.

- Improvements to service delivery and control.

- Access to specific skills or expertise.

* Corresponding author: otebiringa@yahoo.com

DOI:10.5937/sjm9-5626 
- Transformation, modernization and innovation of businesses.

In recent times, cost savings tends to have been perceived as the secondary reason for offshoring by most researchers. This is because, as Barthélemy (2003) posit organisations have achieved cost savings through offshoring with some significant level of value compromise.

Ideally, business strategies differentiates organisations innovation proposals through lower costs, via improved processes, better use of resources, improved management techniques and output delivery, unfortunately this does not always happen (Bertrand, 2011). Cost savings has in some cases has been being achieved through some unethical practices (Brown \& Wilson, 2005) which makes such cost savings unsustainable. Doh et al. (2009) insist that if offshoring delivers cost saving without additional value created for the organization and its partners, the offshoring organisation could probably have achieved the same or even a better result, by effecting changes inhouse. Delivering efficient and sustainable cost savings often represent key risk for offshoring, as cost savings need to be balanced with service quality, regulations and value created for stakeholders (Economist, 2013).

Throughout the life of an offshoring engagement, attention should be paid to developing a value-based relationship framework that addresses the various stages of work - from proposal, to contract, to imple $\neg$ mentation and renewal (Doh et al., 2011). An effective offshoring relationship as reported by Farrell (2005) should align with the level of value exchange agreed to by both parties, and structured according to the type of alliance.

Cadbury Nigeria Plc in the last quarter of
2012 adopted value management initiative (VMI) and outsourced sorghum supply, a basic input to its production process to outside vendors. The objective of VMI is to engage vendors on a negotiated forward purchase agreement in order to hedge the fundamental increase of duty and levy; take advantage of the favourable commodity price; keep low inventory; free up cash for other priority working capital needs; increase potential capacity of investable funds; reduce days inventory holding index and cash conversion circle.

\section{PROBLEM STATEMENT \& NEED FOR THE STUDY}

Organisations outsource variety of activities in order to achieve specific objective, which includes reducing costs (Feeny et al., 2005; Graf \& Mudambi, 2005; Grimpe \& Kaiser, 2010), improving product quality (Hatonen, 2009), improving flexibility (Hui et al., 2008), increasing market coverage (Jensen, 2009), or perhaps to gain ready access to additional capacity (Jensen \& Pedersen, 2012). Kedia and Lahiri (2007) insist that most atimes firms set cost reduction targets as specific objective of offshoring, with actual savings coming from direct labor and variable costs. But the extent value management factors are compromised in the process of implementing offshoring strategy remains a research issue (Kumar et al., 2009). There is relatively little empirical inquiry into the factors associated with sustainable cost reduction when offshoring especially in the Nigerian manufacturing industry.

This paper seek to evaluate the extent to which adoption of offshoring strategy by Cadbury Nigeria Plc for the supply of 
sorghum, a critical input to her production process has achieved the stated objectives of cost savings, low inventory, freed up cash for other priority working capital, value created for business partners as well identify risk dimensions that may make the policy unsustainable. The paper therefore seeks to provide answer to the following research question based on empirical evidences:

- What is the level of cost savings that Cadbury Nigeria Plc has been able to achieve through offshoring, one year after the policy was introduced?

- To what extent has adoption of offshoring by Cadbury Nigeria freed funds previously held in inventory for other working capital needs?

- What are the key sustainability factors of the financial benefits of offshoring strategy in Cadbury Nigeria Plc?

\section{THEORETICAL FRAMEWORK}

Researchers have used many theoretical perspectives for investigating the efficacy of offshoring decisions (Lahiri \& Kedia, 2011). Theories such as Transaction Cost Economics and the Resource-Based View of the firm predict that under the right conditions, offshoring reduces operating cost (Lampel \& Bhalla, 2011). Larsen et al. (2013) posit that firms must consider the cost benefit tradeoff between in-house execution of a process and the offshoring of the same process as the principle determinant. Lahiri et al. (2012) insist that in as much as financial performance metrics are good measure of the effectiveness of offshoring decision but some non-financial aggregate may affect the sustainability of financial benefits in the long run if not properly considered.

Empirical evidence suggests, however, that firms do not always experience sustainable growth in financial performance when offshoring some activities of their operation (Leisch et al., 2012) due largely to some compromises on value management factors. This failure may be due to competitive priorities that emphasize more on cost savings and less on consumer satisfaction and retention; employee motivation and satisfaction; vendor satisfaction and retention. Risk mitigating and co-operate reputation are another set of factors. Luo et al. (2012) based on their study of offshoring in India and China found that partnership involvement, knowledge sharing, and innovation have a significant effect on offshoring performance. Manning and Sydow (2011) on the other hand while investigating the effects of offshoring strategy on Projects, Paths, and Practices for sustaining and Leveraging Project-Based Relationships, found that offshoring could have impact on some managerial and strategic aspects of supply chain management of projects.

Manning et al. (2011) and Jensen and Pedersen (2011) are in agreement that the performance of offshoring firms when investigated using financial benefits related performance measures in short and long term and must be further evaluated along with operational/channel and relational dimensions using such indices as partnership awareness, shared goals and risk mitigation etc as shown on Figure 1.

Making the right offshoring decision requires a clear understanding of the broad array of potential engagement options, risks and benefits, and the appropriateness of each potential arrangement for meeting business objectives. Many variations of offshoring 
alternatives according to Kedia and Mukherjee (2009) exist, resulting in a lexicon of terms, such as out-tasking, collocation, managed services and business process offshoring. This has led to confusion for many managers, who feel pressure to make the right decisions and often view offshoring as an all or nothing proposition to offload and bring down the costs of noncore activities.

In fact, one of the biggest misconceptions about offshoring is that it is a fixed event or a simple make-or-buy decision. In reality, offshoring is an umbrella term that encompasses a spectrum of arrangements, each with unique advantages and risks (Martinez-Noya et al., 2013). Understanding the relative risks and benefits of each of the potential alternatives is critical in making the right offshoring decision.

\section{OFFSHORING: THE GLOBAL EXPERIENCES}

Offshoring a strategy of organizational management has become a megatrend in many industries, most particularly in logistics and supply chain management (Feeny et al., 2005). The overall scope of offshoring is continuing to grow, as firms are increasingly focusing on their core competencies and shedding tasks perceived as noncore (Mudambi \& Tallman, 2010). Recent findings has shown that offshoring of human resources (HR) functions is pervasive, with 94 percent of firms offshoring at least one major HR activity, and the majority of firms planning for offshoring expansion (Mudambi \& Venzin, 2010). Equally the offshoring of sales, marketing and administrative functions provides parallel results, with at least portions of these functions now being

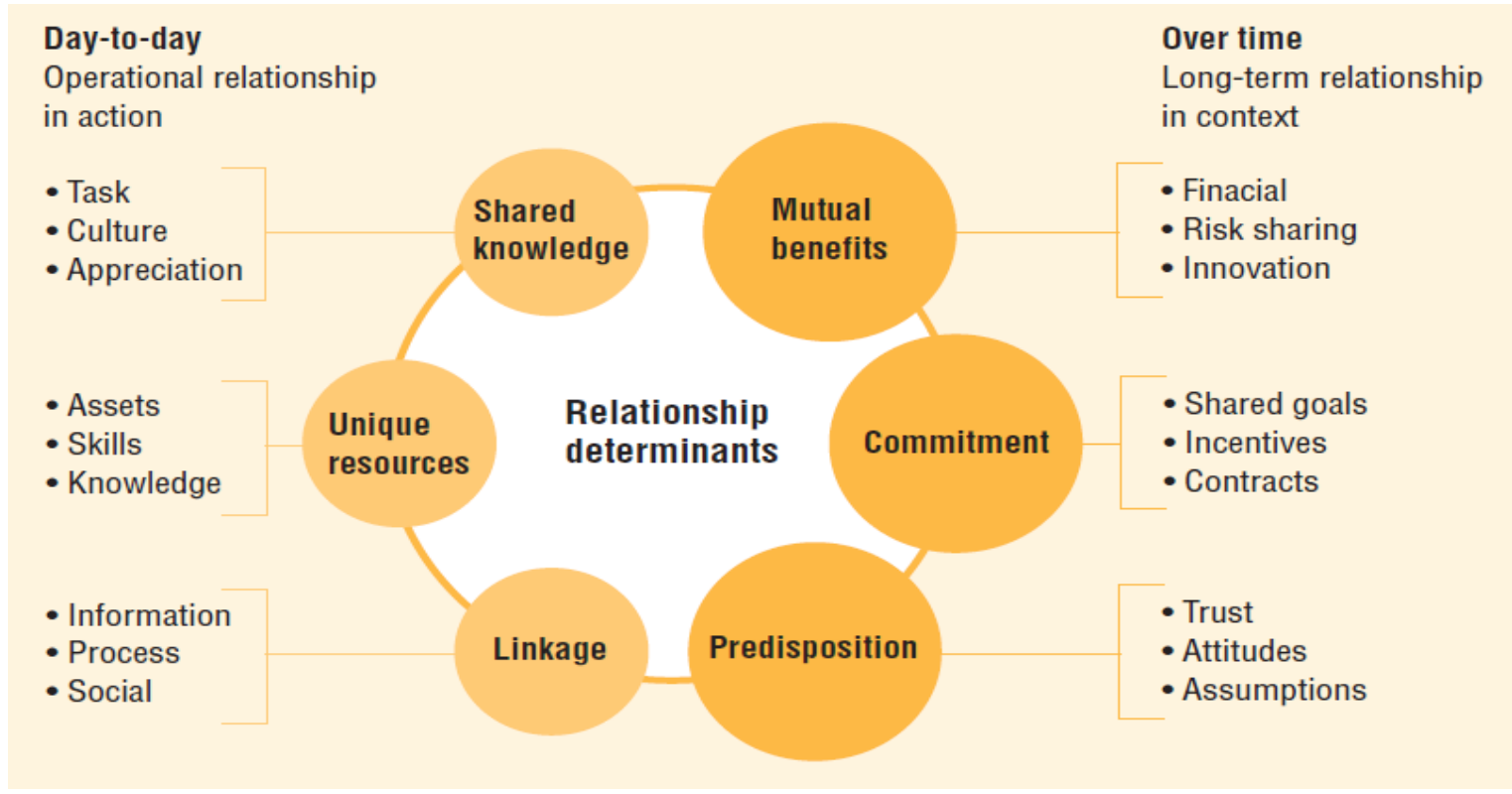

Figure1. Relationship Matters in Offshoring Engagement 
outsourced ranging from 15-50 percent (Mukherjee \& Bhalla, 2010). Similarly, Narayanan et al. (2011) reported that the third- and fourth-party logistics industries are booming, with between 65 percent and 80 percent of U.S. manufacturing firms contracting with or considering use of a logistics service provider. Thus, managers are increasingly feeling pressure to make the right offshoring decision, as the business consequences can be significant (Economist, 2013). Good offshoring decisions can result in lowered costs and competitive advantage, whereas poorly made offshoring decisions can lead to a variety of problems, such as increased costs in the long run, disrupted service and even business failure and poor co-operate image (Mukherjee \& Kedia, 2012). Poor offshoring practices can also lead to an unintended loss of operational level knowledge by the firm.

Consider the case of Toyota Motor Corp., which by offshoring the design and manufacture of electrical systems for its automobiles, surrendered its own capability to understand the processes required for this highly specialized work. As a result, Toyota is no longer able to leverage its own technological advantage with respect to these systems during product development (Nieto \& Rodriguez, 2011). Problems such as these and others related to the offshoring of operations and services are prevalent when offshoring arrangements are not well understood by in-house managers as well employees of vendor firms. To such problem Tata has been able to mitigate (Tata Consultancy Service, 2012).

In the 1990s, according to Reizeig and Wagner (2010) offshoring was the focus of many industrial manufacturers; firms considered offshoring everything from the procurement function to production and manufacturing. Executives focused on stock value, and huge pressure was placed on increasing profits. Of course, one easy way to increase profit is by reducing costs through offshoring. Indeed, in the mid 90s there was a significant increase in purchasing volume as a percentage of the firm's total sales. Between 1998 and 2000, offshoring in the electronics industry increased from 15 percent of all components to 40 percent.

Consider, for instance, the athletic shoe industry, a fashion industry with products that require significant investment in technology. No company in this industry has been as successful as Nike, a company that outsources almost all its manufacturing activities (Sirmon et al., 2010).

Nike, the largest supplier of athletic shoes in the world, focuses mainly on research and development on the one hand and marketing, sales, and distribution on the other. Indeed, this strategy allowed Nike to grow in the 1990s at an annual rate of about 20 percent.

Cisco's success story is even more striking. According to Peter Solvik, CIO of Cisco, Cisco's Internet-based business model was instrumental in its ability to quadruple in size from 1994 to 1998 (\$1.3 billion to over $\$ 8$ billion), hire approximately 1000 new employees per quarter while increasing their productivity, and save $\$ 560$ million annually in business expenses. Specializing in enterprise network solutions, Cisco used, according to John Chambers, Cisco CEO, a global virtual manufacturing strategy. As he explained:"First, we have established manufacturing plants all over the world. We have also developed close arrangements with major suppliers. So when we work together with our suppliers, and if we do our job right, the customer cannot tell the difference between my own plants and my suppliers in Taiwan and elsewhere". 
This approach was enabled by Cisco's single enterprise system, which provides the backbone for all activities in the company and connects not only customers and employees but also chip manufacturers, component distributors, contract manufacturers, logistics companies, and systems integrators (Srikanth \& Puranam, 2010). These participants can perform like one company because they all rely on the same Web based data sources. All its suppliers see the same demand and do not rely on their own forecasts based on information flowing from multiple points in the supply chain. Cisco also built a dynamic replenishment system to help reduce supplier inventory. Cisco's average inventory turns in 1999 were 10 compared with an average of 4 for competitors. Inventory turns for commodity items are even more impressive; they reach 25 to 35 turns a year.

Apple Computers also outsources most of its manufacturing activities; in fact, the company outsources 70 percent of its components. Apple focused its internal resources on its own disk operating system (DOS) and the supporting macro software to give Apple products their unique look and feel.

\section{RESEARCH METHOD}

The study is an investigative and used a combination of secondary and primary source data in the assessment of the effect of offshoring strategy on sustainable financial benefit to partners. Secondary data includes published in-house and outsourced financial performance information (supply cost and inventory holding) of Cadbury Nigeria Plc as it relates to supply of Sorghum for twelve (12) months period, while primary data is made up weighted responses of Cadbury staff directly involved in inventory management to questions as to how offshoring has affected key value management drivers (awareness of offshoring requirements, shared goals, financial profitability and risk mitigation).

A combination of paired sample and one sample t-test formed the tool of analysis. The paired samples t-test compares the means of in-house $\left(\mathrm{X}_{1}\right)$ and outsourced $\left(\mathrm{X}_{2}\right)$ costs. The objective is to test whether the average difference is significantly different from zero.

$$
\begin{aligned}
& \bar{d}=\mu_{1}-\mu_{2} \\
& d=\sum x / n
\end{aligned}
$$

$H_{a}: \bar{d} \int 0$ (non directional)

Standard Error $=\mathrm{SE}_{\text {diff }}=\mathrm{s}_{\text {diff }} / \operatorname{sqrt}(\mathrm{n})$

The t-value calculates is the ratio of a statistic divided by the standard error.

$t_{S}=\frac{\bar{d}}{S E_{\bar{d}}}$

for $\mathrm{n}-1$ degrees of freedom.

\section{One Sample t-test}

The One Sample t-test returns the probability for the Student t-distribution where a numeric value $(x)$ is a calculated value of " $t$ " for which the probabilities are computed. The t-distribution is used in testing our hypothesis given that our sample 
(70) is small. The function used in place of a table of critical values for the t-distribution is:

\section{Syntax}

\section{TDIST(x,degrees_freedom,tails)}

$\mathbf{X}$ is the numeric value at which to evaluate the distribution.

Degrees_freedom is an integer indicating the number of degrees of freedom.

Tails specifies the number of distribution tails to return. If tails $=1$, TDIST returns the one-tailed distribution. If tails $=2$, TDIST returns the two-tailed distribution.

\section{Decision Rules}

- If any argument is nonnumeric, TDIST returns the \#VALUE! error value.

- If degrees_freedom $<1$, TDIST returns the \#NUM! error value.

- The degrees_freedom and tails arguments are truncated to integers.

- If tails is any value other than 1 or 2 ,
TDIST returns the \#NUM! error value.

- If $\mathrm{x}<0$, then TDIST returns the \#NUM! error value.

- If tails $=1$, TDIST is calculated as TDIST $=\mathrm{P}(\mathrm{X}>\mathrm{X})$, where $\mathrm{X}$ is a random variable that follows the $t$-distribution. If tails $=2$, TDIST is calculated as TDIST $=$ $\mathrm{P}(|\mathrm{X}|>\mathrm{x})=\mathrm{P}(\mathrm{X}>\mathrm{x}$ or $\mathrm{X}<-\mathrm{x})$.

- Since $\mathrm{x}<0$ is not allowed, to use TDIST when $\mathrm{x}<0$, note that TDIST(-x,df,1) $=1-\operatorname{TDIST}(\mathrm{x}, \mathrm{df}, 1)=\mathrm{P}(\mathrm{X}>-\mathrm{x})$ and

- $\operatorname{TDIST}(-\mathrm{x}, \mathrm{df}, 2)=\operatorname{TDIST}(\mathrm{x}$ df,2) $=$ $\mathrm{P}(|\mathrm{X}|>\mathrm{x})$.

\section{RESULTS AND DISCUSSIONS}

Table 1 is an extract from the report of Sorghum offshoring Committee as at last quarter of 2013.

The recommended offshoring cost based on equalization of the weighted tendered cost of the seven vendors ( $\$ 1,376.00$ per Tonne) is 12.0 percent less than the in-house cost (\#81,552.00 per Tonne) as per budget by Cadbury. The above vendor costs include a profit margin of 7.0 percent ( $\$ 4,987.00$ per Tonne) ${ }^{1}$.

Table 1. Offshoring Quotation Cost Vs In-house Cost

\begin{tabular}{|c|c|c|c|c|c|c|c|c|c|c|}
\hline $\begin{array}{l}\text { QUOTATION - } \\
\text { EQUALIZED }\end{array}$ & $\begin{array}{c}\text { Vendor } \\
1\end{array}$ & $\begin{array}{l}\text { Vendor } \\
2\end{array}$ & $\begin{array}{c}\text { Vendor } \\
3\end{array}$ & $\begin{array}{l}\text { Vendor } \\
4\end{array}$ & $\begin{array}{l}\text { Vendor } \\
5\end{array}$ & $\begin{array}{l}\text { Vendor } \\
6\end{array}$ & $\begin{array}{c}\text { Vendor } \\
7\end{array}$ & $\begin{array}{c}\text { Weight } \\
\text { ed } \\
\text { Avrg } \\
\end{array}$ & $\begin{array}{l}\text { Recom- } \\
\text { dd Avrg }\end{array}$ & $\begin{array}{c}\text { In- } \\
\text { house }\end{array}$ \\
\hline Base Price $(\mathrm{N} / \mathrm{T})$ & 48,000 & 48,000 & 48,000 & 48,000 & 48,000 & 48,000 & 48,000 & 48,000 & 48,000 & 48,000 \\
\hline Process Loss & 1,440 & 1,440 & 960 & 1,440 & 1,070 & 1,297 & 1,120 & 1,252 & 1,153 & 3,222 \\
\hline $\begin{array}{l}\text { Cost of cleaning \& } \\
\text { Bagging }\end{array}$ & 1,059 & 1,038 & 0 & 3,216 & 1,394 & 1,152 & 1,344 & 1,315 & 1,210 & 3,222 \\
\hline Finance Charge & 8,904 & 6,071 & 7,360 & 6,263 & 9,535 & 4,586 & 1,507 & 6,318 & 5,815 & 8,873 \\
\hline Storage Cost & 934 & 1,443 & 4,297 & 2,784 & 2,675 & 2,439 & 2,333 & 2,415 & 2,223 & 3,212 \\
\hline Transport Cost & 6,071 & 6,030 & 6,621 & 5,616 & 5,851 & 5,062 & 5,280 & 5,790 & 5,329 & 6,000 \\
\hline $\begin{array}{l}\text { Other Admin } \\
\text { (Sal,Wages,Admin) }\end{array}$ & 2,752 & 2,538 & 4,800 & 3,372 & 914 & 2,285 & 0 & 2,380 & 2,191 & 4,511 \\
\hline Others & 1,895 & 1,394 & $(0)$ & 0 & 274 & 0 & 0 & 509 & 468 & 4,511 \\
\hline Margin & 7,063 & 4,077 & 7,850 & 7,069 & 5,653 & 3,241 & 2,979 & 5,419 & 4,987 & 0 \\
\hline Total & 78,118 & 72,033 & 79,888 & 77,760 & 75,366 & 68,061 & 62,563 & 73,398 & 71,376 & 81,552 \\
\hline
\end{tabular}

Source: Cadbury Inventory Tracker, 2013

1 \# - Nigerian monetary unit "Naira" 
6.1. Analysis of Effect of Offshoring on Cost Savings

All aspects of the cost variables (Table 1), shows that offshoring performed better than in-house except for base price for which inhouse cost and outsourced cost are same. The cost savings achieved through offshoring is \#10176.00 per tonne.

The above finding provides a positive answer to our research question 1:

"Cadbury Nigeria Plc was able to achieve \#10176.00 per tonne cost savings when compared to in-house cost through offshoring. When this is multiplied by the 18,000tonne annual capacity demand it gives $\$ 183,175,740.00$ cost savings one year after the policy was introduced".

When the above answer is tested for statistical significance using the result of the paired sample t- test of Table 2 data as shown on Table 3. The tcal. Value of -1.303 is significant at 0.229 level, implying that at 0.05 level the cost saving recorded one year after adoption of offshoring by Cadbury for the supply of sorghum is not significant.

\subsection{Offshoring Freeing Cash held in Inventory}

Table 4 shows that as at July 2013 Cadbury Nigeria has successful freed itself from investment in inventory holding of sorghum and outsourced all monthly inventory demand needed to support production to vendors. This translates to \#4,646,943.73 per tonne worth of funds freed for other working capital needs. The annual worth based on 18000 tonnes demand is $\$ 83,644,987,140.00$. The above finding

Table 2. Disaggregation of Inventory Cost into Cost Centers

\begin{tabular}{lcccc}
\hline Cost Variables & $\begin{array}{c}\text { Outsourced } \\
(\mathbf{A m})\end{array}$ & $\begin{array}{c}\text { In-house } \\
(\mathbf{A m})\end{array}$ & $\begin{array}{c}\text { Difference } \\
(\mathbf{A m})\end{array}$ & $\begin{array}{c}\% \\
\text { contribution }\end{array}$ \\
\hline Base Price $(\mathrm{N} / \mathrm{T})$ & 48000.00 & 48000.00 & 0.00 & 0.0 \\
Process Loss \% & 1153.00 & 3222.00 & -2069.00 & 20.33 \\
Cost of cleaning \& Bagging \% & 1210.00 & 3222.00 & -2012.00 & 19.86 \\
Finance Charge & 5815.00 & 8873.00 & -3058.00 & 30.05 \\
Storage Cost & 2223.00 & 3212.00 & -989.00 & 9.72 \\
Transport Cost & 5329.00 & 6000.00 & -671.00 & 6.59 \\
Other Admin (Sal,Wages,Admin) & 2191.00 & 4511.00 & -2320.00 & 22.80 \\
Others & 468.00 & 4511.00 & -4043.00 & 39.73 \\
Margin & 4987.00 & 0.00 & 4987.00 & 49.01 \\
Total & $\mathbf{7 1 , 3 7 6 . 0 0}$ & $\mathbf{8 1 , 5 5 2 . 0 0}$ & $\mathbf{- 1 0 1 7 6 . 0 0}$ & $\mathbf{1 0 0 . 0 0}$ \\
\hline
\end{tabular}

Source: Cadbury Inventory Tracker, 2013

Table 3. Paired Samples Test

\begin{tabular}{|c|c|c|c|c|c|c|c|c|}
\hline & \multicolumn{5}{|c|}{ Paired Differences } & \multirow[b]{3}{*}{$\mathrm{t}$} & \multirow[b]{3}{*}{ df } & \multirow{3}{*}{$\begin{array}{l}\text { Sig. (2- } \\
\text { tailed) }\end{array}$} \\
\hline & \multirow[b]{2}{*}{ Mean } & \multirow{2}{*}{$\begin{array}{c}\text { Std. } \\
\text { Deviation }\end{array}$} & \multirow{2}{*}{$\begin{array}{c}\text { Std. Error } \\
\text { Mean }\end{array}$} & \multicolumn{2}{|c|}{$\begin{array}{l}95 \% \text { Confidence } \\
\text { Interval of the } \\
\text { Difference }\end{array}$} & & & \\
\hline & & & & Lower & Upper & & & \\
\hline Pair 1 outsourced - inhouse & -1130.56 & 2602.97 & 867.66 & -3131.38 & 870.27 & -1.303 & 8 & .229 \\
\hline
\end{tabular}

Source: Result of Computer Analysis with SPSS for Windows 
provides a positive answer to our research question 2:

"Cadbury freed \$83,644,987,140.00 cash previously held in inventory for other working capital investment activities through offshoring, 12 months after adopting the strategy".

When the above answer is tested for statistical significance using the result of the paired sample t- test of Table 4 data as shown on Table 5.

Tcal value of -6.415 of Table 5 shows at 0.01 level, a significant negative difference exist between cash freed from inventory holding as a result of implementing offshoring strategy. The conclusion therefore is that offshoring of supply of sorghum to vendors by Cadbury Nigeria led significant availability of cash for investment in other working capital needs of the firm.

\subsection{Profit Created by Offshoring Strategy for Cadbury Business Partners}

In assessing the extent to which offshoring has created value for Cadbury business partners in this case the vendors, we refer to Table 6 with specific focus on the margin allowed in the offshoring contract. The offshoring contract allowed vendors to recover all associated cost of doing the business including the financing cost which is 8.0 percent per annum. The margin of $7 \%$ allowed vendors imply that for every 100 invested by a vendor in inventory holding, a return on investment of 7 percent is achieved. This is clearly a value created which is made possible by the offshoring policy adopted by Cadbury as the in-house option had zero margin. The implication therefore being that between January to

Table 4. Investible Funds Freed Due to Offshoring

\begin{tabular}{cccc}
\hline Period & $\begin{array}{c}\text { Post } \\
\text { Offshoring } \\
2013(\mathbf{A m})\end{array}$ & $\begin{array}{c}\text { Pre Offshoring } \\
2012(\mathbf{A m})\end{array}$ & $\begin{array}{c}\text { Difference } \\
(\mathbf{A m})\end{array}$ \\
\hline Jan & 63993.18 & 243946.40 & -179953.22 \\
Feb & 183791.08 & 161771.80 & 22019.28 \\
Mar & 259605.55 & 836655.55 & -577050.00 \\
Apr & 416914.60 & 889451.34 & -472536.74 \\
May & 292788.98 & 852729.93 & -559940.95 \\
Jun & 196631.93 & 750408.35 & -553776.42 \\
Jul & 0.00 & 591449.78 & -591449.78 \\
Aug & 0.00 & 501839.89 & -501839.89 \\
Sep & 0.00 & 457597.01 & -457597.01 \\
Oct & 0.00 & 407175.58 & -407175.58 \\
Nov & 0.00 & 299456.57 & -299456.57 \\
Dec & 0.00 & 68186.85 & -68186.85 \\
Annual Total & $\mathbf{1 4 1 3 7 2 5 . 3 2}$ & $\mathbf{6 0 6 0 6 6 9 . 0 5}$ & $\mathbf{- 4 6 4 6 9 4 3 . 7 3}$ \\
Monthly Average & $\mathbf{1 1 7 8 1 0 . 4 4}$ & $\mathbf{5 0 5 0 5 5 . 7 5}$ & $\mathbf{- 3 8 7 2 4 5 . 3 1}$ \\
\hline
\end{tabular}

Source: Cadbury Inventory Tracker

Table 5. Paired Samples Test

\begin{tabular}{|c|c|c|c|c|c|c|c|c|}
\hline & \multicolumn{5}{|c|}{ Paired Differences } & \multirow[b]{3}{*}{$\mathrm{t}$} & \multirow{3}{*}{$\mathrm{df}$} & \multirow{3}{*}{$\begin{array}{l}\text { Sig. (2- } \\
\text { tailed) }\end{array}$} \\
\hline & \multirow[b]{2}{*}{ Mean } & \multirow{2}{*}{$\begin{array}{c}\text { Std. } \\
\text { Deviation }\end{array}$} & \multirow{2}{*}{$\begin{array}{l}\text { Std. Error } \\
\text { Mean }\end{array}$} & \multicolumn{2}{|c|}{$\begin{array}{c}95 \% \text { Confidence } \\
\text { Interval of the } \\
\text { Difference }\end{array}$} & & & \\
\hline & & & & Lower & Upper & & & \\
\hline Pair 1 Post Outsource - In-house & $-3.87 \mathrm{E} 5$ & $2.09 \mathrm{E} 5$ & 60365.52 & $-5.20 \mathrm{E} 5$ & $-2.54 \mathrm{E} 5$ & -6.415 & 11 & .000 \\
\hline
\end{tabular}

Source: Result of Computer Analysis with SPSS for Windows 
Table 6. Outsourced Cost Vs In-house Cost Supply of Sorghum

\begin{tabular}{|c|c|c|c|c|c|c|c|c|c|c|}
\hline $\begin{array}{l}\text { QUOTATION - } \\
\text { EQUALIZED }\end{array}$ & $\begin{array}{c}\text { Vendor } \\
1\end{array}$ & $\begin{array}{c}\text { Vendor } \\
2\end{array}$ & $\begin{array}{c}\text { Vendor } \\
3\end{array}$ & $\begin{array}{c}\text { Vendor } \\
4\end{array}$ & $\begin{array}{l}\text { Vendor } \\
5\end{array}$ & $\begin{array}{l}\text { Vendor } \\
6\end{array}$ & $\begin{array}{c}\text { Vendor } \\
7\end{array}$ & $\begin{array}{l}\text { Weighted } \\
\text { Average }\end{array}$ & $\begin{array}{c}\text { Rec. } \\
\text { Average }\end{array}$ & $\begin{array}{l}\text { In- } \\
\text { house }\end{array}$ \\
\hline Base Price (N/T) & $61 \%$ & $67 \%$ & $60 \%$ & $62 \%$ & $64 \%$ & $71 \%$ & $77 \%$ & $65 \%$ & $67 \%$ & $59 \%$ \\
\hline Process Loss \% & $2 \%$ & $2 \%$ & $1 \%$ & $2 \%$ & $1 \%$ & $2 \%$ & $2 \%$ & $2 \%$ & $2 \%$ & $4 \%$ \\
\hline $\begin{array}{l}\text { Cost of cleaning \& } \\
\text { Bagging }\end{array}$ & $1 \%$ & $1 \%$ & $0 \%$ & $4 \%$ & $2 \%$ & $2 \%$ & $2 \%$ & $2 \%$ & $2 \%$ & $4 \%$ \\
\hline Finance Charge & $11 \%$ & $8 \%$ & $9 \%$ & $8 \%$ & $13 \%$ & $7 \%$ & $2 \%$ & $9 \%$ & $8 \%$ & $11 \%$ \\
\hline Storage Cost & $1 \%$ & $2 \%$ & $5 \%$ & $4 \%$ & $4 \%$ & $4 \%$ & $4 \%$ & $3 \%$ & $3 \%$ & $4 \%$ \\
\hline Transport Cost & $8 \%$ & $8 \%$ & $8 \%$ & $7 \%$ & $8 \%$ & $7 \%$ & $8 \%$ & $8 \%$ & $7 \%$ & $7 \%$ \\
\hline $\begin{array}{l}\text { Other Admin } \\
\text { (Sal,Wages) }\end{array}$ & $4 \%$ & $4 \%$ & $6 \%$ & $4 \%$ & $1 \%$ & $3 \%$ & $0 \%$ & $3 \%$ & $3 \%$ & $6 \%$ \\
\hline Others & $2 \%$ & $2 \%$ & $0 \%$ & $0 \%$ & $0 \%$ & $0 \%$ & $0 \%$ & $1 \%$ & $1 \%$ & $6 \%$ \\
\hline \multirow[t]{2}{*}{ Margin } & $9 \%$ & $6 \%$ & $10 \%$ & $9 \%$ & $8 \%$ & $5 \%$ & $5 \%$ & $7 \%$ & $7 \%$ & $0 \%$ \\
\hline & $100 \%$ & $100 \%$ & $100 \%$ & $100 \%$ & $100 \%$ & $100 \%$ & $100 \%$ & $100 \%$ & $100 \%$ & $100 \%$ \\
\hline
\end{tabular}

Source: Computed from Table 4.data

December 2013 Cadbury create additional value for her business partners (vendors) amounting to:

$7 \%$ of ( $\$ 1,413,725.32$ per tonne $\mathrm{X}$ 18000tonnes (annual demand)). = \#1,781,293,903.00

\subsection{Effect of Offshoring on Risk drivers}

Table 7 shows that the five top most outcomes of offshoring strategy in Cadbury Nigeria according to staff are of financial benefits and shared value categories:

- Operations cost savings.

- Rewarding vendors according to level of service quality.

- Promotes teamwork between vendors and internal staff for enhanced productivity.

- Promoted operational efficiency within organisation through partnering.

- Promoted philosophy of zero tolerance for poor service quality.

The implication of the above is that offshoring strategy has had the most significant effect on reducing cost of inventory management, increased co- operation with partnering organisations, leading to increased productivity and service quality. This is consistent with the views of Tadelis (2007). On the other hand the five least effects of offshoring strategy in Cadbury Nigeria are of awareness and risk mitigation categories and includes:

- Vendors take appropriate security measures.

- Organizational risk has reduced.

- The in-house staff feel comfortable entrusting critical activities to vendors.

- It has helped the organization to comply with regulations.

- Vendors have adequate understanding of organization's requirements.

The implication of the above result is that the ability of vendors to have very high understanding of the offshoring requirement of the organisation, willingness of the internal staff to entrust critical activities of the firm to vendors and ability of vendors to take appropriate risk control measures remains non-financial benefits of the offshoring strategy to partners. 
Table 7. Summary of One-Sample t-test and Ranking of Offshoring Risk Drivers

\begin{tabular}{|c|c|c|c|c|c|}
\hline Code & Description of Variable & tcal & df & $\begin{array}{l}\text { Sig. } \\
\text { tailed })\end{array}$ & Ranking \\
\hline A1 & $\begin{array}{l}\text { Vendors display good understanding of offshoring } \\
\text { requirements. }\end{array}$ & 6.327 & 70 & .000 & 17 \\
\hline A2 & Vendors understands firm policy & 9.190 & 70 & .000 & 14 \\
\hline A3 & $\begin{array}{l}\text { Vendors understand the sector in which the firm } \\
\text { operates. }\end{array}$ & 8.168 & 70 & .000 & 15 \\
\hline A4 & Firm understand factors that motivate our vendor. & 13.835 & 70 & .000 & 6 \\
\hline A5 & Vendors clearly understood respective roles of partners & 11.473 & 70 & .000 & 11 \\
\hline B1 & Vendor's objectives and our objectives are well aligned. & 13.698 & 70 & .000 & 7 \\
\hline B2 & $\begin{array}{l}\text { Vendor must partner with internal staff for logistic } \\
\text { productivity to be significantly high }\end{array}$ & 30.397 & 70 & .000 & 3 \\
\hline B3 & $\begin{array}{l}\text { Services provided by our vendor are in accordance with } \\
\text { our organization's requirements }\end{array}$ & 10.239 & 70 & .000 & 12 \\
\hline B4 & $\begin{array}{l}\text { Our vendors are rewarded according to how good their } \\
\text { services are }\end{array}$ & 46.258 & 70 & .000 & 2 \\
\hline B5 & Vendors are penalized for providing bad service. & 15.555 & 70 & .000 & 5 \\
\hline $\mathrm{C} 1$ & $\begin{array}{l}\text { Cost savings from offshoring to vendors is obvious to } \\
\text { employees. }\end{array}$ & 11.708 & 70 & .000 & 10 \\
\hline $\mathrm{C} 2$ & $\begin{array}{l}\text { Cost savings from offshoring to vendor is obvious to } \\
\text { management. }\end{array}$ & 9.783 & 70 & .000 & 13 \\
\hline C3 & Offshoring to vendors helps our firm be more productive. & 26.932 & 70 & .000 & 4 \\
\hline $\mathrm{C} 4$ & Offshoring to vendors saves money for our firm today. & 11.718 & 70 & .000 & 9 \\
\hline $\mathrm{C} 5$ & $\begin{array}{l}\text { Offshoring to our vendors will save money for our firm } \\
\text { in one year's time. }\end{array}$ & 12.281 & 70 & .000 & 8 \\
\hline C6 & $\begin{array}{l}\text { Prices charged by vendors compare favorably with other } \\
\text { similar providers. }\end{array}$ & 7.108 & 70 & .000 & 16 \\
\hline $\mathrm{C} 7$ & In-house delivery of outsourced services is more costly. & 81.423 & 70 & .000 & 1 \\
\hline D1 & $\begin{array}{l}\text { Offshoring to vendor helps our firm comply with } \\
\text { regulations }\end{array}$ & 5.262 & 70 & .000 & 18 \\
\hline D2 & $\begin{array}{l}\text { Vendors can be entrusted with critical activities of our } \\
\text { firm }\end{array}$ & 3.950 & 70 & .000 & 20 \\
\hline D3 & Our vendors take appropriate security measures. & 3.535 & 70 & .001 & 17 \\
\hline D4 & Offshoring to vendors reduces risk for our firm. & 4.358 & 70 & .000 & 14 \\
\hline
\end{tabular}

\section{CONCLUSIONS}

Based on the results obtained the following conclusions are made:

- Cost savings and profitability remains the most critical short run objectives of offshoring strategy in Cadbury Nigeria.

- Increased awareness level of all stakeholders, partnering and shared values between internal staff and vendors and risk mitigation remains sustainability issues of the cost saving and profitability objectives of offshoring.

\section{RECOMMENDATIONS}

Based on the above conclusions the following recommendations are made:

- In order to ensure offshoring leads to sustainable cost savings and profitability for partners international best practices must be adopted in the management of the offshoring value chain.

- Cost saving and profitability should be the short run objectives of offshoring, while value creation and risk mitigation remains the long term objective for 
sustainable cost saving and profitability.

- Offshoring organisations must institute policies of continuous training and awareness creation and co-operation for its personnel (in-house and vendor companies) involved in offshoring. This is to ensure that their knowledge, skill base and business philosophy is updated on regular basis for the good of all parties.

\title{
УПОТРЕБА “ОФ-ШОР” КОНЦЕПТА ЗА ПОСТИЗАЊЕ ОДРЖИВОГ УПРАВЉАЊА ВРЕДНОШЋУ
}

\author{
Thaddeus Oforegbuna Ebiringa, Lasis Kule
}

\section{Извод}

Овај рад се бави проучавањем “оф-шор” концепта као стратешке иницијативе управљања вредношћу, употребом примера компаније “Cadbury" из Нигерије. Назначени су и ризици држања залиха у оваквом концепту пословања. Процењени су ризици концепта пословања у оквиру националне компаније, у поређење са “оф - шор" концептом пословања. Резултати су показали да “оф-шор” доводи до смањења директних трошкова, ослобађања фондова који су претходно били везани у залихама и која се сада могу користити за друге директне инвестиције. Ипак, поред раста финансијских бенефита партнера, овај концепт води и до повећане бриге о стејкхолдерима, поделе вредности, тимског рада и смањења ризика. Одатле следи да се за одржавање финансијских бенефита овог концепта, морају начинити централизовани напори од стране свих партнера да би се обезбедило да кључни фактори управљања вредношћу нису компромитовани.

Кључне речи: Логистика, “Оф-шор”, уштеда, фактор продуктивности, одрживост, стварање вредности.

\section{References}

Andersson, U., \& Pedersen, T. (2010). Organizational design mechanisms for the R\&D function in a world of offshoring. Scandinavian Journal of Management, 26 (4), 431- 438.

Barthélemy, J. (2003). The Seven Deadly Sins of Offshoring, Academy of
Management Executive, 17 (2), 87-100.

Bertrand, O. (2011). What goes around, comes around: Effects of offshore offshoring on the export performance of firms. Journal of International Business Studies, 42 (2), 334-344.

Brown, D., \& Wilson, S. (2005). The 
black book of offshoring: How to manage the changes, challenges, and opportunities. New York: John Wiley.

Doh, J.P., Bunyaratavej, K., \& Hahn, E.D. (2009). Offshoring administrative and technical work: Implications for globalization, corporate strategies, and organizational designs. Journal of International Business Studies, 40, 926-943.

Doh, J., Smith, P., Stumpf, S., \& Tymon, W.G. (2011). Pride and professionals: retaining talent in emerging economies. Journal of Business Strategy, 32, 35-42.

Economist (2013). India's offshoring business on the turn, http://www.economist.com/news/specialreport/21569571-india-no-longer-automaticchoice-it-services-and-back-office-workturn, Accessed on January 19, 2013.

Farrell, D. (2005). Offshoring: Value creation through economic change. Journal of Management Studies, 42 (3), 675-683.

Feeny, D., Lacity, M., \& Willcocks, L. (2005). Taking the measure of offshoring providers. MIT Sloan Management Review, 46 (3), 41-48.

Graf, M., \& Mudambi, S. (2005). The offshoring of IT-enabled business processes: A conceptual model of the location decision. Journal of International Management, 11, 253-268.

Grimpe, C., \& Kaiser, U. (2010). Balancing internal and external knowledge acquisition: the gains and pains from R\&D offshoring. Journal of Management Studies, 47 (8), 1483-1509.

Hatonen, J. (2009). Making the locational choice: A case approach to the development of a theory of offshore offshoring and internationalization. Journal of International Management, 15, 61-76.

Hui, P.P., Davis-Blake, A., \& Broschak,
J.P. (2008). Managing Interdependence: The Effects of offshoring Structure on the Performance of Complex Projects. Decision Sciences, 39 (1), 5-21.

Jensen, P.D. (2009). A learning perspective on the offshoring of advanced services. Journal of International Management, 15 (2), 181-193.

Jensen, P., \& Pedersen, T. (2012). Offshoring and international competitiveness: Antecedents of offshoring advanced tasks. Journal of the Academy of Marketing Science, 40 (2), 313-328.

Jensen, P., \& Pedersen, T. (2011). The Globalization of High-Value Activities: Why do Firms Offshore Advanced Tasks? Journal of Management Studies, 48 (2), 352-372.

Kedia, B.L., \& Lahiri, S. (2007). International offshoring of services: A partnership model. Journal of International Management, 13, 22-37.

Kedia, B.L., \& Mukherjee, D. (2009). Understanding offshoring: A research framework based on disintegration, location and externalization advantages. Journal of World Business, 44 (3), 250-261.

Kumar, K., Van-Fenema, P., \& Von Glinow, M.A. (2009). Offshoring and the global distribution of work: Implications for task interdependence theory and practice. Journal of International Business Studies, 40 (4), 642-667.

Lahiri, S., \& Kedia, B.L. (2011). Coevolution of institutional and organizational factors in explaining offshore offshoring. International Business Review, 20 (3), 252-263.

Lahiri, S., Kedia, B.L., \& Mukherjee, D. (2012). The Impact of Management Capability on the Resource-Performance Linkage: Examining Indian Offshoring Providers. Journal of World Business, 47, 
145-155.

Lampel, J., \& Bhalla, A. (2011). Living with offshoring: The impact of offshoring on the evolution of organizational configurations. Journal of World Business, 46 (3), 346-358.

Larsen, M.M., Manning, S., \& Pedersen, T. (2013). Uncovering the hidden costs of offshoring: The interplay of complexity, organizational design, and experience. Strategic Management Journal, 34, 533-552.

Leisch, P.W., Buckley, P.J., Simonin, B.L., \& Knight, G. (2012). Organizing the modern firm in the worldwide market for market transactions. Management International Review, 52, 3-21.

Luo, Y., Wang, S.L., Zheng, Q., \& Jayaraman, V. (2012). Task attributes and process integration in business process offshoring: A perspective of service providers from India and China. Journal of International Business Studies, 43, 498-524.

Manning, S., \& Sydow, J. (2011). Projects, Paths, and Practices: Sustaining and Leveraging Project-Based Relationships. Industrial and Corporate Change, 20, 13691402.

Manning, S., Lewin, A.Y., \& Schuerch, M. (2011). The Stability of Offshore Offshoring Relationships: The Role of Relation Specificity and Client Control. Management International Review, 51, 381406.

Martinez-Noya, A., Garcia-Canal, E., \& Guillen, M.F. (2013). R\&D Offshoring and the Effectiveness Of Intangible Investments: Is Proprietary Core Knowledge Walking Out The Door? Journal of Management Studies, 50 (1), 67-91.

Mudambi, S.M., \& Tallman, S. (2010). Make, buy or ally? Theoretical perspectives on knowledge process offshoring through alliances. Journal of Management Studies,
47 (8), 1434-1456.

Mudambi, R., \& Venzin, M. (2010). The strategic nexus of offshoring and offshoring decisions. Journal of Management Studies, 47 (8), 1510-1533.

Mukherjee, D., \& Bhalla, A. (2010). Creating Value from Global Offshoring Network: Insights from SAP AG, presented at Academy of International Business Meeting, Rio De Janiero, Brazil.

Mukherjee, D., \& Kedia, B.L. (2012). Offshoring and MNC Strategy. In Merchant, H. \& Verbeke, A. (Eds.), Handbook of Research on International Strategic Management, Elgar Publishing.

Narayanan, S., Jayaraman, V., Luo, Y., \& Swaminathan, M.S. (2011). The antecedents of process integration in business process offshoring and its effect on firm performance. Journal of Operations Management, 29, 3-16.

Nieto, M.J., \& Rodriguez, A. (2011). Offshoring of R\&D: Looking abroad to improve innovation performance. Journal of International Business Studies, 42 (3), 345361.

Reizeig, M., \& Wagner, S. (2010). The hidden costs of offshoring: evidence from patent data. Strategic Management Journal, 31, 1183-1201.

Sirmon, D.G., Hitt, M.A., Arregle, J.L., \& Campbell, J.T. (2010). Capability strengths and weaknesses in dynamic markets: Investigating the bases of temporary competitive advantage. Strategic Management Journal, 31 (13), 1386-1409.

Srikanth, K., \& Puranam, P. (2010). Integrating distributed work: Comparing task design, communication, and tacit coordination mechanisms. Strategic Management Journal, 32 (8), 849-875.

Tadelis, S. (2007). The innovative organization: Creating value through 
offshoring. California Management Review, 50 (1), 261-277.

Tata Consultancy Service. (2012). Annual Report, retrieved from http://www.tcs.com/investors/Documents/A nnual\%20Reports/TCS_Annual_Report_201 1-2012.pdf. 